\title{
Knowledge status of predators of the freshwater prawn Cryphiops caementarius (Decapoda: Palaemonidae) in river systems along the North Western Andean region from Perú and Chile
}

\author{
Carlos Velásquez*, Luis Henríquez-Antipa, Denisse Torres-Avilés, Álvaro E. Wilson, \\ Yeriko Alanís, \& Francisco Cárcamo \\ 1. Instituto de Fomento Pesquero, Dr. Marín 340, Coquimbo, Chile; carlos.velasquez@ifop.cl, luis.henriquez@ifop.cl, \\ denisse.torres@ifop.cl, alvaro.wilson@ifop.cl,yeriko.alanis@ifop.cl, francisco.carcamo@ifop.cl \\ * Correspondence
}

Received 25-III-2020. C Corrected 28-V-2020. Accepted 03-VIII-2020.

\begin{abstract}
Introduction: Cryphiops caementarius, is an endemic prawn from river ecosystems in Southern Perú and Northern Chile. In these watersheds, natural populations are threatened by multiple anthropic interventions such as mining activities and fishing pressure, but also, by increasing impacts of invasive exotic predators. Information related with predation on C. caementarius is scarce representing a major knowledge gap to ensure suitable management and conservation practices. Accordingly, the further deepening in relevant aspects such as the estimation of populations losses due to predators has been indicated as critical by relevant agencies as FAO. Objective: To conduct a complete registry and classification of $C$. caementarius predators, updating the knowledge for the Andean region. Methods: A thorough bibliographic review on existing information on C. caementarius' predators from Perú and Chile was carried out calculating percentage of occurrence, relative frequency of species, zoogeographic origin, trophic structure, phenotypic attributes, river zone that inhabits and life stage of incidence. The registry was complemented using semi-structured interviews from prawn's fishers in central-Northern Chile. Results: C. caementarius is predated along the entire fluvial network (estuary, potamon and rhithron) by 21 species of opportunists, carnivores, omnivores and herbivores, mostly aquatic vertebrates. In turn, these belong to 15 families and six guilds of native, exotic and cosmopolitan species. Approximately $86 \%$ predate on adult prawns, whilst, $71 \%$ on juveniles and $24 \%$ on larvae. More than $40 \%$ of the predation pressure seems to be exerted by native waterfowls and $24 \%$ by exotic fish. Conclusions: The results emphasize the relevance for conservation of native species of predators in the Andean region and the need of control measures on exotic species in a latitudinal basis. Accordingly, this review may serve as an initial decision-making tool for future conservation efforts both on prawns and native biota, but also supporting restocking actions, fisheries management plans and risk assessment for $C$. caementarius populations across the Andean region.
\end{abstract}

Key words: native predators; exotic species; freshwater crustaceans.

Velásquez, C., Henríquez-Antipa, L., Torres-Avilés, D., Wilson, A.E., Alanís, Y., \& Cárcamo, F. (2020). Knowledge status of predators of the freshwater prawn Cryphiops caementarius (Decapoda: Palaemonidae) in river systems along the North Western Andean region from Perú and Chile. Revista de Biología Tropical, 68(4), 1062-1072.

The freshwater prawn, Cryphiops caementarius (Molina, 1782), is a species that undergoes a traditional fishery in river systems located in the western slope of the Andean region of Perú and Chile from the Chancay and Lambayeque rivers in Northern Perú (ca. $6^{\circ} \mathrm{S}$ ) to Aconcagua river in central-Northern Chile (ca. 33으) (Bahamonde \& Vila, 1971) (Fig. 1). 


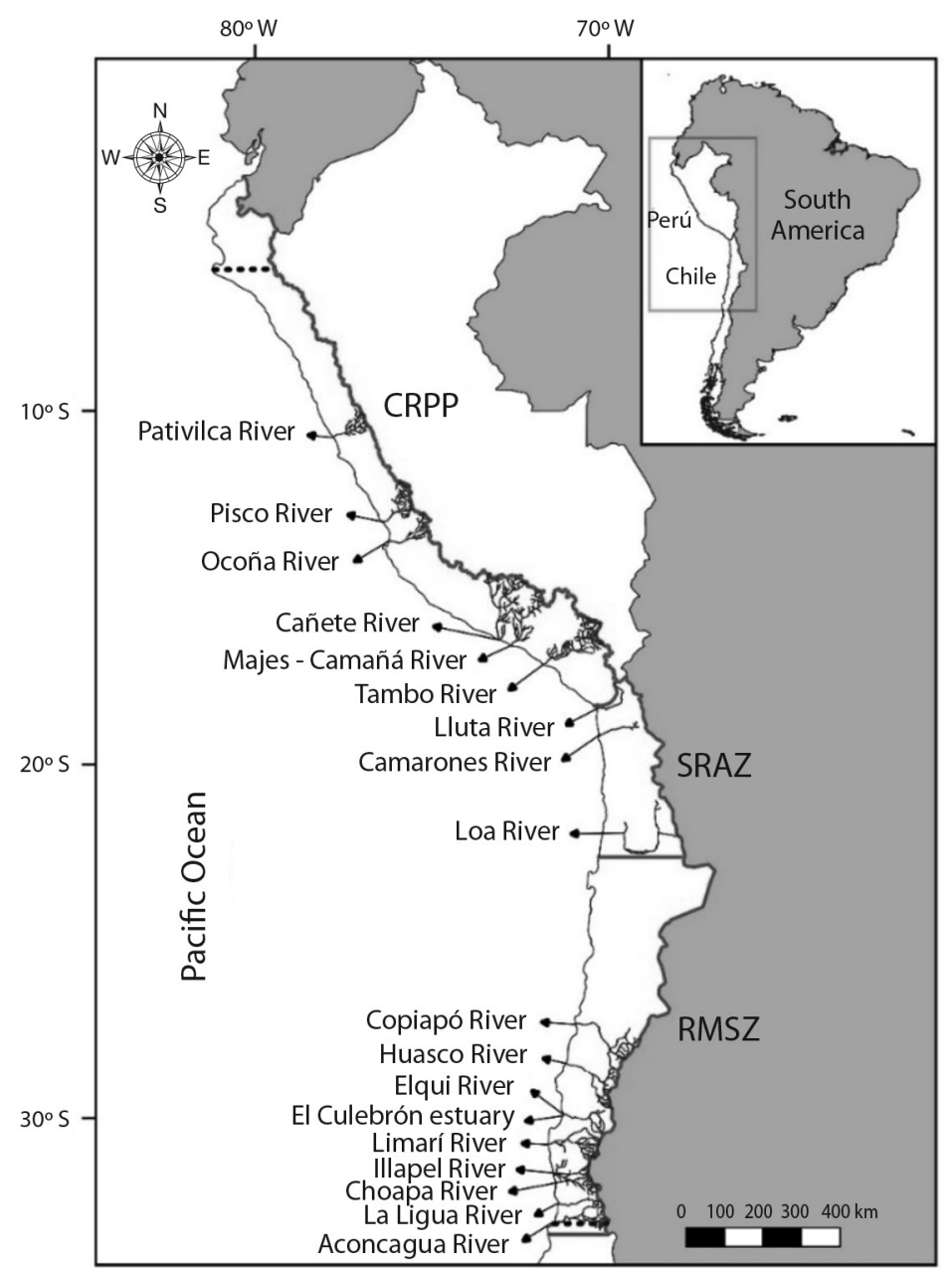

Fig. 1. Geographic scope according literature review in the North Western Andean region of Perú and Chile. The dashed black line indicates the latitudinal range of distribution of Cryphiops caementarius. The continuous black line indicates hydrographic zones. CRPP = continental region of the Pacific of Perú, SRAZ = sporadic rivers in the Northern arid zone from Chile, RMSZ = rivers from mixed regime in the semi-arid zone of central-Northern Chile.

In this area, prawn's populations are threatened by extended periods of drought, severe anthropic intervention on the riverbed such as mining activities, arids extraction, channeling, implementation of dams and fishing pressure (Morales \& Meruane, 2013 a). In addition, the presence of exotic predatory fish such as the trout Oncorhynchus mykiss (Walbaum, 1792) (Bahamonde \& Vila, 1971; Viacava, Aitken, \& Llanos, 1978) and the cichlid Australoheros facetus (Jenyns, 1842) recently documented in
El Culebrón estuary (ca. $29^{\circ} \mathrm{S}$; central-Northern Chile) (Avilés, López, \& Flores, 2018).

However, these factors do not exclusively affect $C$. caementarius, but most of the species of freshwater prawns worldwide (e.g. Bowles, Aziz, \& Knight, 2000; Snyder, Anderson, \& Pringle, 2011). For this reason, the Food and Agriculture Organization of the United Nations (FAO; http://www.fao.org) indicates the need to further deepen in relevant aspects of these organisms such as: a) the ethology of juveniles, 
b) infectiology and parasitology, and c) the quantitative estimation of populations losses due to predation. Accordingly, information related with key ecological interactions such as predation is scarce representing a major knowledge gap to guarantee correct management and conservation practices (Parsons, 2005).

Cryphiops caementarius is one of the most studied prawns across the Andean region (Jara, Rudolph, \& González, 2006) with extensive reviews on natural history, fishing and cultivation (e.g. Bahamonde \& Vila, 1971; Morales \& Meruane, 2013 a, b). To date, 69 articles and technical reports have been published on $C$. caementarius in Perú and Chile. From these, only 23 are currently indexed on SCOPUS (IFOP, 2019). These articles include eight subjects: a) aquaculture and physiology $(\mathrm{N}=$ $25 ; 36.3 \%), \mathrm{b})$ fishery $(\mathrm{N}=16 ; 23.2 \%), \mathrm{c})$ biology and morphology $(\mathrm{N}=10 ; 14.5 \%), \mathrm{d})$, ecology $(\mathrm{N}=4 ; 5.8 \%)$, e) diet $(\mathrm{N}=3 ; 4.3 \%)$, f) systematics and phylogeny $(\mathrm{N}=2 ; 2.9 \%)$, g) economic studies $(\mathrm{N}=2 ; 2.9 \%)$, and $\mathrm{h})$ others $(\mathrm{N}=7 ; 10.1 \%)$. These figures suggest that relevant aspects indicated by FAO (e.g. ecology) are poorly documented. Hence, the main objective of this work is to conduct a bibliographic review of the existing background information on C. caementarius' predators in the North Western watersheds of the Andean region of Perú and Chile. Also, this register was complemented with semi-structured interviews from prawn's fishers. Then, the state of knowledge of this species is discussed in function of potential ecological and trophic implications of predator's species on the populations of $C$. caementarius emphasizing the relevance of conservation of the diversity of native predators in the Andean region.

\section{MATERIAL AND METHODS}

Spatial scope: The study included information from 18 rivers distributed in the North Western margin of the Andean region from Pativilca River (ca. $10^{\circ} \mathrm{S}$; Southern Perú) to Aconcagua River (ca. $33^{\circ} \mathrm{S}$; central-Northern Chile) (Fig. 1). The river systems occur in three well-defined areas: a) continental region of the Pacific of Perú (CRPP) (six rivers; $33.3 \%$ ), b) sporadic rivers in the Northern arid zone from Chile (SRAZ) (three rivers; $16.7 \%$ ), and c) rivers from mixed regime in the semi-arid zone of central-Northern Chile (RMSZ) (nine rivers; $50.0 \%$ ) (Fig. 1) (cf. Niemeyer \& Cereceda, 1984; Aguirre, Ruiz, \& Torres, 2005).

Bibliographic revision and semi-structured interviews: The collection of information was carried out through an exhaustive review of scientific journals, academic thesis, government and academic web platforms. A total of nine studies were collected from Perú (42.9\%) and 12 from Chile (57.1\%), covering the last 62 years (1958-2019) (Digital Appendix 1). In addition, semi-structured interviews were performed during March 2019 in two commercial prawn fisher organizations $(\mathrm{N}=$ 17) from the rivers Illapel and Choapa (ca. $31^{\circ} \mathrm{S}$; central-Northern Chile). The age group of interviewees varied between 29-65 years old and included four women $(23.5 \%)$ and 13 men $(76.5 \%)$. The interviewees answered three questions: a) what animals have you observed feeding on prawns? b) have you ever observed prawns in the stomach of some animals? Then, which ones? and c) have you ever observed cannibalism among prawns? If so, can you explain under what circumstances?

Knowledge status of predatory species: This was evaluated by reviewing targeted literature of inland waters from Perú and Chile and traditional knowledge of commercial fisher organizations of Chilean prawn about: C. caementarius (Bahamonde \& Vila, 1971), leeches (Tello, Jerez, \& Olmos, 2007; Christoffersen, 2009), fish (Arratia, 1981; Dyer, 2000; Ortega, Guerra, \& Ramírez, 2007; Cossíos, 2010; Avilés, López, \& Flores, 2018), frogs (Charrier, 2019), waterfowls (Schulenberg, Stotz, Lane, O'Neill, \& Parker, 2010; Medrano, Barros, Norambuena, Matus, \& Schmitt, 2018) and mammals (Bastida, Rodríguez, Secchi, \& da Silva, 2007). For each species was determined family, zoogeographic origin (native, 
exotic, cosmopolitan), trophic functional group (carnivore, omnivore, herbivore), phenotypic attributes (opportunist and selective), distribution zone (estuary, potamon, rhithron) and the ontogenic stage of $C$. caementarius preferred as prey (trophic amplitude).

Ontogenic stages were classified according to cephalothorax length into larvae (since ca. $0.4 \mathrm{~mm})$, juveniles $(>2.5 \mathrm{~mm})$ and adults (ca. $22.0 \mathrm{~mm}$ ) (Morales, Meruane, Galleguillos, Rivera, \& Hosokawa, 2006). Due to the lack of clarity about the identity of fish of the genus Basilichthys and Odonthestes in the literature, these were referred generically as silversides. The proportion of species was determined through percentage of occurrence frequency (OF) for each species in the total number of rivers and relative frequency $(\mathrm{RF})$, which corresponds to $\mathrm{RF}=\left(\mathrm{fi} / \sum \mathrm{fi}\right) \times 100$, where $\mathrm{fi}=$ number of times a species was registered and $\sum \mathrm{fi}=$ the total number of records of all species.

\section{RESULTS}

Species richness and frequency: A total number of 21 species were recorded consisting in two macroinvertebrates, including leeches $(4.8 \%)$ and prawns $(4.8 \%)$ and 19 vertebrates, including nine waterfowl (42.9\%), six fish $(28.5 \%)$, two frogs $(9.5 \%)$, and two mammals (9.5\%) (Fig. 2A). These species are distributed within 15 families, mainly represented by Ardeidae $(\mathrm{N}=4 ; 19.0 \%)$, Laridae and Salmonidae ( $\mathrm{N}=2 ; 9.5 \%$, respectively). The species richness varied from 15 at the RMSZ to 12 on the SRAZ, geographic overlapping was registered in $52.4 \%(\mathrm{~N}=11)$ of the total number of species. Whilst, $47.6 \%(\mathrm{~N}=$ 10) of the species was found only within one hydrographic zone. At local level, species richness varied from a maximum of 10 on Illapel and Choapa rivers (ca. $31^{\circ} \mathrm{S}$; central-Northern Chile) to a minimum of two on Cañete River (ca. $12^{\circ} \mathrm{S}$; Southern Perú) (Digital Appendix 2 and Digital Appendix 3).
Considering the total community and excluding humans, waterfowls were the most common species as follows: the great egret Ardea alba (Linnaeus, 1758) (OF $=66.7$ $\% ; \mathrm{RF}=9.8 \%$ ), the snowy egret Egretta thula (Molina, 1782) $(\mathrm{OF}=55.6 \%$; RF $=8.2 \%)$ and the black-crowned night-heron Nycticorax nycticorax (Linnaeus, 1758) (OF $=55.6 \%$; $\mathrm{RF}=8.2 \%)$. C. caementarius reached an $\mathrm{OF}$ $=55.6 \%$, RF $=8.2 \%$, whilst, the Neotropical cormorant Phalacrocorax brasilianus (Gmelin, 1789) showed a $\mathrm{OF}=44.4 \%$; $\mathrm{RF}=6.6 \%$. The mosquitofish Gambusia affinis (Baird \& Girard, 1853) $(\mathrm{OF}=44.4 \%$; RF $=6.6 \%)$ and O. mykiss $(\mathrm{OF}=44.4 \%$; $\mathrm{RF}=6.6 \%)$ also were present (Digital Appendix 3).

Semi-structured interviews: The group interviews yielded the following results: a) the main predators of $C$. caementarius at Illapel and Choapa river included five species of waterfowls (A. alba, the cocoi heron Ardea cocoi (Linnaeus, 1766), E. thula, N. nycticorax and $P$. brasilianus), two fish (the common carp Cyprinus carpio (Linnaeus, 1758) and $O$. mykiss), and the Chilean giant frog Calyptocephalella gayi (Duméril \& Bibron, 1841) (Fig. $3)$, b). All interviewees declared to have found remains of prawns in the stomach content of the locally consumed frog $C$. gayi, c) all interviewees agreed that the river prawn is a species that showed cannibalism, in particular among individuals that happen to use the same lair.

Knowledge status of the species: The zoogeographic origin of species (including Perú and Chile), was represented by three categories: native $(\mathrm{N}=14 ; 66.6 \%)$, exotic $(\mathrm{N}=6$; $28.6 \%$ ) and cosmopolitan ( $\mathrm{N}=1 ; 4.8 \%$ ) (Fig. 2B). The trophic structure, was represented by three functional groups: carnivores $(\mathrm{N}=12$; $57.2 \%)$, omnivores $(\mathrm{N}=8 ; 38.0 \%)$, and herbivores $(\mathrm{N}=1 ; 4.8 \%$ ) (Fig. $2 \mathrm{C})$, which represented the two phenotypic attributes described: opportunist $(\mathrm{N}=18 ; 85.7 \%)$ and selective $(\mathrm{N}=$ 3; $14.3 \%$ ) (Fig. 2D). Species distributed within 

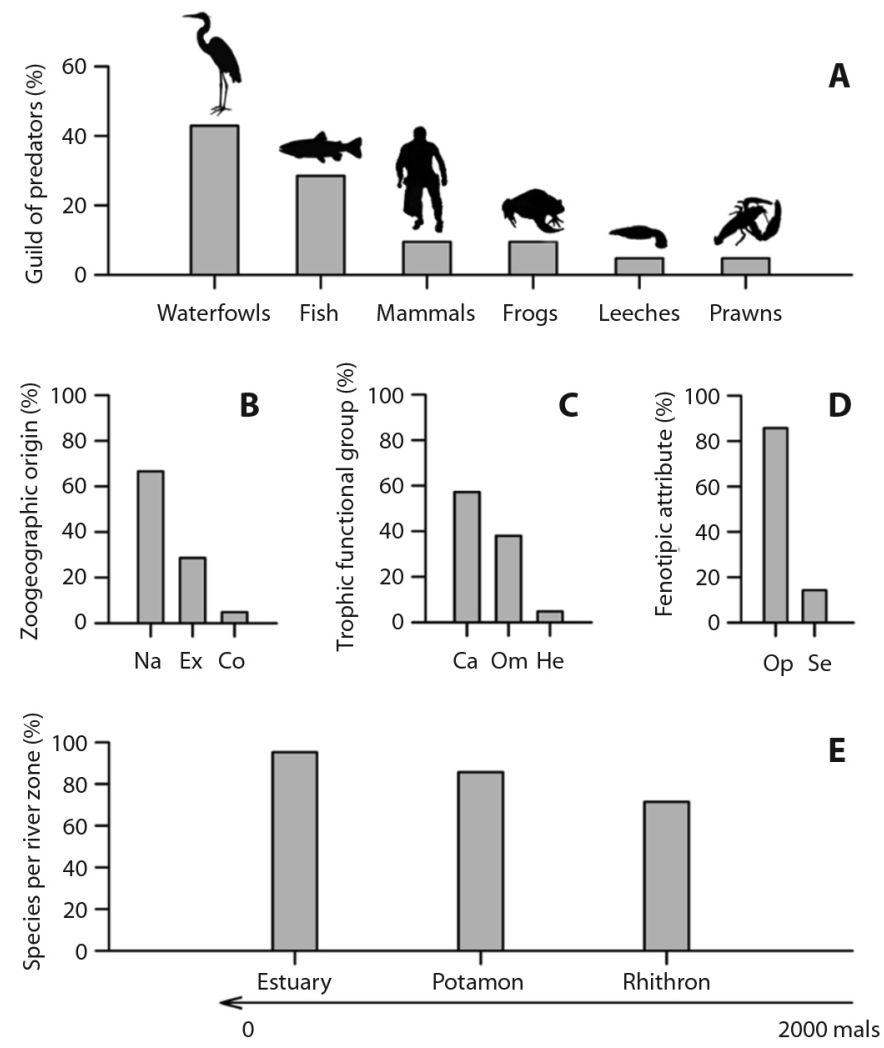

Fig. 2. Percentage of occurrence of predators of Cryphiops caementarius grouped by A. guilds, B. zoogeographic origin (Na $=$ native, $\mathrm{Ex}=$ exotic, $\mathrm{Co}=$ cosmopolitan $), \mathbf{C}$. trophic functional group $(\mathrm{Ca}=$ carnivore, $\mathrm{Om}=$ omnivore, $\mathrm{He}=$ herbivore $)$, D. phenotypic attribute $(\mathrm{Op}=$ opportunist, $\mathrm{Se}=$ selective) and $\mathbf{E}$. river zones (mals; meter above level sea).

estuaries were $95.2 \%(\mathrm{~N}=20), 85.7 \%$ at the potamon $(\mathrm{N}=18)$ and $71.4 \%$ at the rhithron $(\mathrm{N}=15)$ (Fig. 2E). These species inhabit at least two zones of the river $(85.7 \% ; \mathrm{N}=18)$, whilst $14.3 \%(\mathrm{~N}=3)$, inhabits one zone (Digital Appendix 2). The $61.9 \%(\mathrm{~N}=13)$ of the species predates on two ontogenic phases of $C$. caementarius, but $28.6 \%(\mathrm{~N}=6)$ on just one. On the contrary, only $9.5 \%(\mathrm{~N}=2)$ presents a trophic range that include all three phases (Fig. $4)$, whilst $85.7 \%(\mathrm{~N}=18)$ of these species predates on the adult portion of the prawn's population, the $71.4 \%(\mathrm{~N}=15)$ on juveniles and $23.8 \%(\mathrm{~N}=5)$ on larval stages (Fig. 4).

\section{DISCUSSION}

Cryphiops caementarius encompasses an important food item for a wide range of taxa as well as a source of livelihood for commercial fishers. In nature, the presence of predators extends throughout all zones of the river, but they are particularly abundant $(>90 \%)$ in estuaries, probably due to the greater productivity of these biomes. More than $40 \%$ of the total predation pressure seems to be exerted by native waterfowls. Interestingly, an important fraction $(23.8 \%)$ is potentially carried out by exotic fish (e.g. salmonids). This predators 


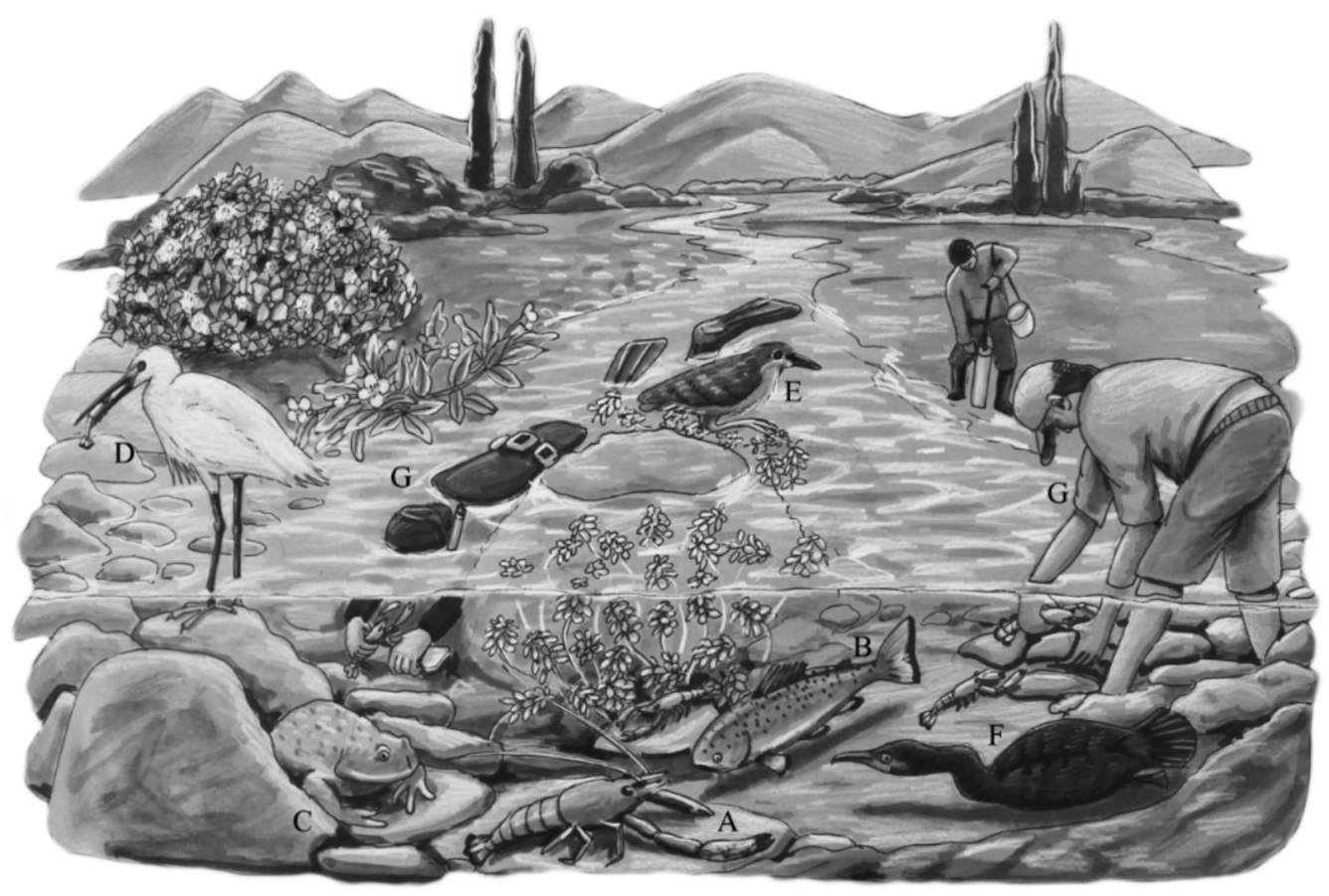

Fig. 3. Suite of main predators of Cryphiops caementarius in environments from Northern Chile. A. C. caementarius, B. Oncorhynchus mykiss, C. Calyptocephalella gayi, D. Egretta thula, E. Nycticorax nycticorax, F. Phalacrocorax brasilianus, G. prawn fisher. Illustration: Jano Ramos.

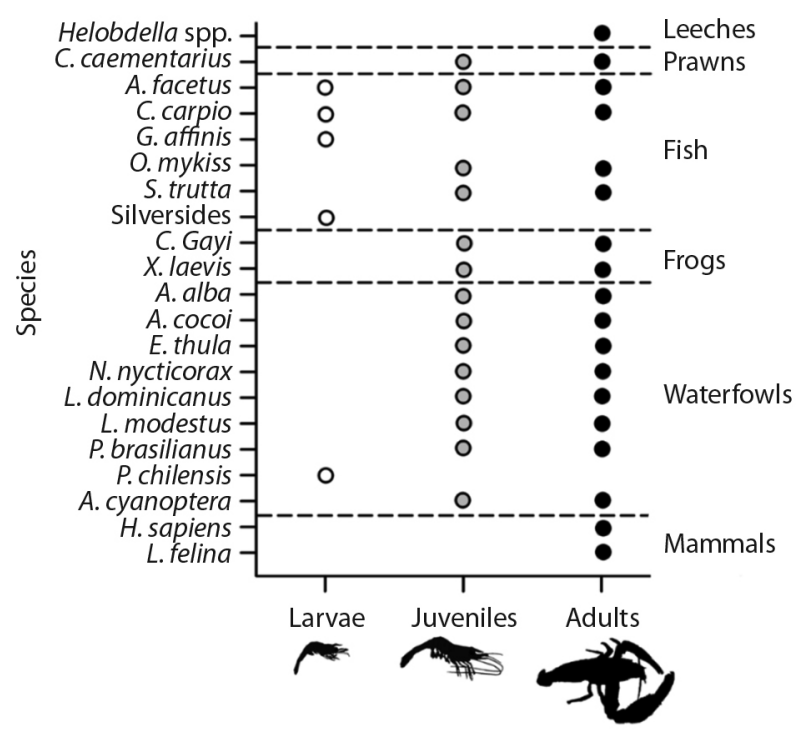

Fig. 4. Trophic amplitude of predatory species on ontogenic stages of Cryphiops caementarius. Larvae (white dots), juveniles (gray dots), adults (black dots). Dotted line indicates guilds of predators. 
matches those described for similar species of Neotropical prawns and crayfish, such as Macrobrachium tenellum (Smith, 1871) (Espinosa-Chaurand et al., 2011), Palaemonetes argentinus (Nobili, 1901) (Collins, Williner, \& Giri, 2004), Samastacus spinifrons (Philippi, 1882) and Parastacus pugnax (Poeppig, 1835) (Rudolph, 2013). In addition, similarly to other species of palaemonid prawns when faced with food shortage, C. caementarius adopts cannibalistic behaviour. However, this study suggests that this effect may be minor compared with other predators. Nevertheless, cannibalism in C. caementarius have been confirmed by the narrative of commercial fishers in Illapel and Choapa rivers, and has also, been observed under experimental laboratory conditions (Morales \& Meruane, 2013 b).

It is important to highlight that exotic fish predators such as $O$. mykiss, the brown trout Salmo trutta (Linnaeus, 1758), C. carpio and G. affinis, have been identified within the list of the 100 world's worst invasive alien species by the International Union for Conservation of Nature (IUCN; http://www.iucn.org). Currently, these species are all present in inland waters from Perú and Chile, along with $A$. facetus and the African frog Xenopus laevis (Daudin, 1802), which have been listed by the Chilean Ministry of Environment (MMA) as exotic species of major concern (https://www. especies-exoticas.mma.gob.cl).

The impact of exotic predatory species on native fauna goes further predation. Sublethal effects, usually of unknown extent on the trophic interactions and habitat displacement have been documented in earlier studies. Among these predators, the fish as $A$. facetus is the only species that have evidenced until $50 \%$ of $C$. caementarius in stomach content (Áviles, López, \& Flores, 2018). On the contrary, there's no direct evidence of predation on $C$. caementarius by $G$. affinis, but this species is a well-known active predator of planktonic microcrustaceans. However, there is evidence that this species competes directly for food and shelter with prawns, such as Palaemon antennarius (H. Milne Edwards, 1837) and Atyaephyra thyamisensis (Christodoulou, Antoniou, Magoulas, \& Koukouras, 2012) (Gkenas, Oikonomou, Economou, Kiosse, \& Leonardos, 2012). On the other hand, X. laevis, $O$. mykiss and S. trutta are notable predators of benthic macroinvertebrates, including crustaceans (Encina, Vega, Lara, \& Ríos-Escalante, 2017; Charrier, 2019). However, so far, studies on these predators have not detected $C$. caementarius as a food item in the diet of these fish, but this may be due that study areas were outside the habitat range of $C$. caementarius. On the other hand, the recent documented expansion of $X$. laevis into river systems of central-North Chile (Mora et al., 2019), suggests emergent effects on C. caementarius populations comparable to those exerted by the salmonids on the crayfish $S$. spinifrons (Encina Vega, Lara, \& Ríos-Escalante, 2017), a species with similar habits of those observed in $C$. caementarius. The uncontrolled introduction of exotic species corresponds to the second cause of extinction after habitat fragmentation, and therefore, a major threat to world's biodiversity (Doherty, Glen, Nimmo, Ritchie, \& Dickman, 2016). Accordingly, the introduction and subsequent geographic expansion of exotic predators appears as a major risk for C. caementarius. In addition, this may have important implications for commercial fisher's livelihood from the Andean region of Perú and Chile. In this context, the ecological role of native predators, such as herons, cormorants and frogs in controlling exotic species in the Andean region such as the salmonids (Alarcón, Macchi, Trejo, \& Alonso, 2012), C. carpio (Pérez, De Lope, Turégano, \& De la Cruz, 1991), G. affinis (Ashoori, Varasteh-Moradi, Reza-Rezaiee, \& Salman-Mahiny, 2017) and the frog $X$. laevis (Mora, Constanzo-Chávez, Contardo, \& Labra, 2016; Charrier, 2019), emerges as of utmost relevance. This have been suggested by Hammerschlag et al. (2019) as one of the many ecosystem functions/services provided by native predators in an ever-changing environment. However, some native predators as the frog C. gayi are in high risk, because it is target of illegal fishing pressure since is considered 
a culinary delight (Charrier, 2019). This suggests, that furtive fishers may facilitate the prevalence of exotic species by eliminating native predators and competitors. The background information provided in this study stresses out the need of enforcing conservation measures for the protection of native predators in particular, those from ecosystems subjected to high anthropic perturbations as river basins.

From a fisheries perspective, the extraction of $C$. caementarius in Chile is carried out under an open-access regime but the activity has not been legally recognized by the National Fisheries Authority. Basic aspects of fisheries as the up-to-date knowledge of landings are still incomplete at least in Chile (Digital Appendix 4). Nevertheless, from 1986 several regulations were proposed including a summer-mid autumn harvest ban, a permanent ban on ovigerous females and a minimum harvest size (30 $\mathrm{mm}$ cephalothorax length). However, enforcement and compliance on these regulations are unknown. On the other hand, C. caementarius have been classified as of Least Concern species, due to lack of basic information and inconsistent updating of population dynamics (IFOP, 2019). Fortunately, since 2013 the species has been categorized as Vulnerable by the MMA (https://www.clasificacionespecies.mma.gob. $\mathrm{cl}$ ), and the IUCN, which has included C. caementarius in the red list of threatened species (https://www.iucnredlist.org). Currently, natural populations in Northern Chile are facing the worst drought in recent years (https://www.cr2. $\mathrm{cl} /$ megasequia). This have been accentuated by water shortage mitigating measures promoted by Chilean government through direct physical alteration of rivers. Furthermore, a recent study has reported a drastic reduction in the original spatial distribution of $C$. caementarius in the Choapa River (IFOP, 2019). Accordingly, as an amphidromous species is highly susceptible to habitat modification and connectivity disruptions across the basins (Morales \& Meruane, 2013 a).

The information gathered in this review can be useful for enabling the risk assessment of $C$. caementarius populations in river systems of the Andean region illustrating the exotic predator's guilds that may threaten prawns' populations. Likewise, it can act as supporting information for selection criteria for conservation or restocking initiatives, and the implementation of extinction risk assessment, a tool widely used for species inhabiting altered environments. This review has shown that $C$. caementarius seems to support a wide range of predators from the Andean region, however, these includes fast-spreading exotic species. The later may be detrimental for natural populations along the entire watersheds inhabited by the species. In turn, this may have further social-ecological implications for ecosystems and people since the most of basins are subjected to additional anthropogenic uses. The lack of information and the complexity of the multiple interactions with predators suggests a risk scenario for $C$. caementarius. The present work can underpin and guide either conservation and management programs able to support three main axes for socio-ecological development: (1) suitable watershed administration, (2) fisheries recognition towards conservation and (3) improved control of introduced-invasive species. At this regard, implementation of hatchery reared juveniles and fully implemented restocking programs could be established along with protection of the waterways, at the least, as a precautionary principle. This will be achieved in a first stage only after official governmental recognition of $C$. caementarius as an endangered fishing resource that support both natural heritage and social-ecological systems from the Andean region.

Ethical statement: authors declare that they all agree with this publication and made significant contributions; that there is no conflict of interest of any kind; and that we followed all pertinent ethical and legal procedures and requirements. All financial sources are fully and clearly stated in the acknowledgements section. A signed document has been filed in the journal archives. 


\section{ACKNOWLEDGMENTS}

This work was supported by the Grant "Consolidation program of the Aquaculture Fisheries Strategy (AFS) of the freshwater prawn Cryphiops caementarius in the basin of the Choapa River" funded for Regional Government of Coquimbo, Chile (Code BIP: 30480241-0).

\section{RESUMEN}

Estado del conocimiento de los depredadores del camarón de río Cryphiops caementarius (Decapoda: Palaemonidae) en sistemas fluviales del Noroeste de la región Andina de Perú y Chile. Introducción: Cryphiops caementarius es un camarón endémico de los ecosistemas fluviales del sur de Perú y norte de Chile. En estas cuencas hidrográficas, las poblaciones naturales están amenazadas por múltiples intervenciones antrópicas, como la actividad minera y presión pesquera, pero también por el creciente impacto de depredadores exóticos invasores. Información relacionada con la depredación sobre C. caementarius es escasa, representando una brecha de conocimiento importante para asegurar apropiadas prácticas de manejo y conservación. En consecuencia, la profundización en aspectos relevantes como la estimación de las pérdidas de población debido a los depredadores, ha sido indicada como crítica por agencias relevantes como FAO. Objetivo: Realizar un registro completo y clasificación de los depredadores de $C$. caementarius, actualizando el conocimiento para la región Andina. Métodos: Se realizó una revisión bibliográfica exhaustiva de la información existente sobre los depredadores de $C$. caementarius de Perú y Chile, calculando el porcentaje de frecuencia de ocurrencia y frecuencia relativa para cada especie, además de su respectivo origen zoogeográfico, estructura trófica, atributo fenotípico, zona fluvial que habita y etapa de la vida de incidencia del camarón. El registro se complementó con entrevistas semi-estructuradas a pescadores de camarones del centro-norte de Chile. Resultados: $C$. caementarius es depredado en diferentes zonas de la red fluvial (estuario, potamon y ritron) por 21 carnívoros, omnívoros y herbívoros, oportunistas y selectivos, en su mayoría vertebrados acuáticos. A su vez, estos se distribuyen en 15 familias y seis gremios, pertenecientes a tres categorías de origen zoogeográfico (nativo, exótico y cosmopolita). Aproximadamente el $86 \%$ de estas especies depreda sobre la fracción adulta, mientras que el $71 \%$ lo hace sobre juveniles y el $24 \%$ sobre estadios larvales. Las aves acuáticas nativas ejercen más del $40 \%$ de la presión depredadora, seguido por peces exóticos con un $24 \%$. Conclusiones: Los resultados enfatizan sobre relevancia que tiene la conservación de depredadores nativos en la región Andina y la necesidad de medidas de control sobre especies exóticas. En consecuencia, esta revisión puede servir como una herramienta inicial de toma de decisiones para futuros esfuerzos de conservación tanto de camarones como de la biota nativa, pero también apoyando acciones de gestión pesquera y evaluación de riesgos para $C$. caementarius en toda la región Andina.

Palabras clave: depredadores nativos; especies exóticas; crustáceos dulceacuícolas.

\section{REFERENCES}

Aguirre, M., Ruiz, R., \& Torres, H. (2005). Delimitación y codificación de cuencas hidrográficas del Perú. Lima, Perú: Instituto Nacional de Recursos Naturales, Intendencia de Recursos Hídricos.

Alfaro, D., Bueno, G., Mardones, A., Neira, A., Segovia, E., \& Venegas, E. (1980). Contribución al conocimiento de Cryphiops caementarius (Molina, 1782) Loa, Antofagasta (Tesis). Universidad de Chile, Santiago, Chile.

Alarcón, P.A., Macchi, P.J., Trejo, A., \& Alonso, M.F. (2012). Diet of the Neotropical Cormorant (Phalacrocorax brasilianus) in a Patagonian freshwater environment invaded by exotic fish. Waterbirds, 35, 149-153.

Apaza, R. (2018). Evaluación de la biodiversidad asociada a Cryphiops caementarius (camarón de río) en el Río Tambo- Arequipa, 2017-2018 (Tesis). Universidad Nacional de San Agustín de Arequipa, Arequipa, Perú.

Arratia, G. (1981). Géneros de peces de aguas continentales de Chile. Museo Nacional de Historia Natural de Chile, 34, 1-108.

Ashoori, A., Varasteh Moradi, H., Rezaiee, H.R., \& Mahiny, A.S. (2017). Nest position, breeding success and diet of the Black-crowned Night Heron, Nycticorax nycticorax in the Anzali Wetland, Northern Iran (Aves: Ardeidae). Zoology in the Middle East, 63, 283-290.

Avilés, J., López, A., \& Flores, H. (2018). Interacciones tróficas de Australoheros facetus (Perciformes: Cichlidae), pez exótico en el humedal El Culebrón, Coquimbo, Chile. Revista de Biología Marina y Oceanografia, 53, 99-105.

Bahamonde, N., \& Vila, I. (1971). Sinopsis sobre la biología del camarón de río del norte. Biología Pesquera, $5,1-60$.

Bastidas, R., Rodríguez, D., Secchi, E., \& da Silva, V. (2007). Mamíferos acuáticos de Sudamérica y Antártida. Buenos Aires, Argentina: Vazquez Mazzini Editores.

Bocardo, E., Morales, A., \& Yipita, R. (2007). Análisis de la densidad poblacional de Cryphiops caementarius en la desembocadura de un sistema de drenaje en 
Punta de Bombón, Arequipa-Perú. Revista BIOS, 2, 42-51.

Bowles, D. E., Aziz, K., \& Knight, C. L. (2000). Macrobrachium (Decapoda: Caridea: Palaemonidae) in the contiguous United States: a review of the species and an assessment of threats to their survival. Journal of Crustacean Biology, 20, 158-171.

Busse, K., \& Schlatter, R. (1965). Seminario sobre la biología y métodos de explotación del camarón de río del norte de Chile (Cryphiops caementarius (Molina.)) (Tesis). Universidad de Chile, Santiago, Chile.

Castro, C. (1966). El Camarón de Río del Norte Cryphiops caementarius (Molina). Estudios Oceanológicos, 2, 11-19.

Charrier, A. (2019). Anfibios de los bosques de la zona centro sur y Patagonia de Chile. Guía de campo. Biobío-Ñuble, Chile: Ediciones Corporación Chilena de la Madera.

Christoffersen, M.L. (2009). A catalogue of Helobdella (Annelida, Clitellata, Hirudinea, Glossiphoniidae), with a summary of leech diversity, from South America. Neotropical Biology and Conservation, 4, 89-98.

Collins, P.A., Williner, V., \& Giri, F. (2004). Crustáceos Decápodos del Litoral Fluvial Argentino. En F.C. Aceñolaza (Ed.), Temas de la biodiversidad del litoral fluvial argentino (pp. 253-264). Tucumán, Argentina: INSUGEO, Miscelánea.

Concha, R. (2018). Evaluación de la Población de Cryphiops caementarius (Molina, 1782) en el Rio Tambo, Arequipa, 2016 (Tesis). Universidad Nacional de San Agustín de Arequipa, Arequipa, Perú.

Cortés, S. (1999). Consideraciones sobre la biología poblacional del camarón de rio del norte (Cryphiops caementarius Molina 1782) durante épocas de mediana pluviosidad y de sequía extrema en el rio Choapa, IV Región (Tesis). Universidad Católica del Norte, Coquimbo, Chile.

Cossíos, E.D. (2010). Vertebrados naturalizados en el Perú: historia y estado del conocimiento. Revista Peruana de Biología, 17(2), 179-189.

De los Ríos-Escalante, P., Adamowicz, S., \& Witt, J. (2010). Aquatic fauna in the driest desert on earth: first report on the crustacean fauna of the Loa river (Atacama Desert, Antofagasta region, Chile). Crustaceana, 83, 257-266.

Doherty, T.S., Glen, A.S., Nimmo, D.G., Ritchie, E.G., \& Dickman, C.R. (2016). Invasive predators and global biodiversity loss. Proceedings of the National Academy of Sciences, 113, 11261-11265.

Dyer, B.S. (2000). Systematic review and biogeography of the freshwater fishes of Chile. Estudios Oceanológicos, 19, 77-98.
Elías, J. (1960). Contribución al conocimiento del camarón de río del norte Cryphiops caementarius (Molina, 1782) Decapoda: Palaemonidae. Pesca y Caza, $10,84-106$

Encina, F., Vega, R., Lara, G., \& De los Ríos-Escalante, P. (2017). Ecological role of benthic crustaceans in Chilean North Patagonian lakes and rivers (Araucania region, $\left.39^{\circ} \mathrm{S}\right)$. Crustaceana, 90, 437-447.

Espinosa-Chaurand, L.D., Vargas-Ceballos, M.A., Guzmán-Arroyo, M., Nolasco-Soria, H., Carrillo-Farnés, O., Chong-Carrillo, O., \& Vega-Villasante, F. (2011). Biología y cultivo de Macrobrachium tenellum: estado del arte. Hidrobiológica, 21, 98-117.

Gkenas, C., Oikonomou, A., Economou, A., Kiosse, F., \& Leonardos, I. (2012). Life history pattern and feeding habits of the invasive mosquitofish, Gambusia holbrooki, in Lake Pamvotis (NW Greece). Journal of Biological Research, 17, 121-136.

Hammerschlag, N., Schmitz, O.J., Flecker, A.S., Lafferty, K.D., Sih, A., Atwood, T.B., ... Cooke, S.J. (2019). Ecosystem function and services of aquatic predators in the Anthropocene. Trends in Ecology \& Evolution, 34(4), 369-383.

Hartmann, G. (1958). Apuntes sobre la biología del camarón de río Cryphiops caementarius (Molina) Palaemonidae. Pesca y Caza, 8, 17-28.

Hernández, J. (1974). El camarón de río Cryphiops caementarius (Molina). Revista Documenta, 47, 36-45.

IFOP. (2019). Programa para la consolidación de la Estrategia Pesquero Acuícola (EPA) del camarón de rio del norte (Cryphiops caementarius) en la cuenca hidrográfica del Río Choapa ( $2^{\circ}$ Informe de Avance). Coquimbo, Chile: Instituto de Fomento PesqueroGobierno Regional de Coquimbo

Jara, C., Rudolph, E., \& González, E. (2006). Estado del conocimiento de los Malacostráceos dulceacuícolas de Chile. Gayana, 70, 40-49.

López, M., Segovia, E., \& Alfaro, D. (1986). Microalgas: su importancia como recurso alimentario del Camarón de Río del Norte de Chile, Cryphiops caementarius (Molina, 1782). Medio Ambiente, 78, 39-47.

Medrano, F., Barros, R., Norambuena, H.V., Matus, R., \& Schmitt, F. (2018). Atlas de las aves nidificantes de Chile. Santiago, Chile: Red de Observadores de Aves y Vida Silvestre de Chile.

Morales, M.C., Meruane, J., Galleguillos, C., Rivera, M., \& Hosokawa, H. (2006). Morphological characterization of larval stages and first juvenile of freshwater prawn Cryphiops caementarius (Molina 1782) (Decapoda: Palaemonidae) under laboratory conditions. Aquaculture, 261, 908-931. 
Morales, M.C., \& Meruane, J. (2013a). The Northern river shrimp Cryphiops caementarius (Decapoda, Palaemonidae). Research chronology between 1958 and 2008, I: distribution, population status, biology and life cycle. Crustaceana, 86, 1441-1451.

Morales, M.C., \& Meruane, J. (2013b). The Northern river shrimp Cryphiops caementarius (Decapoda, Palaemonidae). Research chronology between 1958 and 2008, II: aquaculture research and development in Northern Chile. Crustaceana, 86, 1452-1467.

Morales, J. (2019). Análisis poblacional del “camarón de rio" Cryphiops caementarius (Crustacea: Decapoda) en el Río Tambo, Arequipa, 2017 (Tesis). Universidad Nacional de San Agustín de Arequipa, Arequipa, Perú.

Mora, M.C., Constanzo-Chávez, J., Contardo, J.E., \& Labra, A. (2016). First report of predation by Calyptocephalella gayi upon the invasive species Xenopus laevis (Amphibia, Anura, Calyptocephalellidae and Pipidae). Herpetology Notes, 9, 171-173.

Mora, M., Pons, D.J., Peñafiel-Ricaurte, A., AlvaradoRybak, M., Lebuy, S., \& Soto-Azat, C. (2019). High abundance of invasive African clawed frog Xenopus laevis in Chile: challenges for their control and updated invasive distribution. Management of Biological Invasions, 10, 377-388.

Niemeyer, H., \& Cereceda, P. (1984). Hidrografia. Geografia de Chile, Tomo VIII. Santiago, Chile: Instituto Geográfico Militar.

Norambuena, R. (1977). Antecedentes biológicos de Cryphiops caementarius (Molina, 1782) en el estero "El Culebrón" (Crustacea, Decapoda, Palaemonidae). Biología Pesquera, 9, 7-19.

Ortega, H., Guerra, H., \& Ramírez, R. (2007). The introduction of nonnative fishes into freshwater systems of Perú. In T.M. Bert (Ed.), Ecological and genetic implications of aquaculture activities (pp. 247-278). Dordrecht, The Netherlands: Springer-Verlag.

Parsons, D.G. (2005). Predators of Northern shrimp, Pandalus borealis (Pandalidae), throughout the North Atlantic. Marine Biology Research, 1, 48-58.

Pérez, J.J., De Lope, F., Turégano, B., \& De la Cruz, C. (1991). La alimentación de los pollos de martinete (Nycticorax nycticorax) en Extremadura. Ardeola, 38, 277-287.

Rudolph, E.H. (2013). Freshwater malacostracans in Chilean inland waters: a checklist of the Chilean Parastacidae (Decapoda, Astacidea). Crustaceana, 86, $1468-1510$

Schulenberg, S.T., Stotz, D.F., Lane, D.F., O'Neill, J.P., \& Parker, T.A. (2010). Birds of Perú. Oxford, U.K: Princeton University Press.

Synder, M.N., Anderson, E.P., \& Pringle, C.M. (2011). A migratory shrimp's perspective on habitat fragmentation in the neotropics: extending our knowledge from Puerto Rico. In A. Asakura (Ed.), New frontiers in crustacean biology. Proceedings of the Crustacean Society summer meeting (pp. 169-182). Tokyo, Japan: Brill.

Tello, P., Jerez, V., \& Olmos, V. (2007). Sanguijuelas (Hirudinea: Glossiphoniidae) asociadas a Cryphiops caementarius (Decapoda: Palaemonidae) del Río Limarí, Chile. Revista de Biología Tropical, 55, 255-260.

Valle, J. (2010). Influencia de las obras de captación en la población de camarones en el río Cañete-propuesta de rehabilitación (Tesis). Universidad Nacional de Ingeniería, Lima, Perú.

Viacava, M., Aitken, R., \& Llanos, J. (1978). Estudio del camarón de río en el Perú, 1975-1976. Boletín Instituto del Mar del Perú, 3, 161-232.

See Digital Appendix at: / Ver Apéndice digital en:

revistas.ucr.ac.cr 